\title{
THE ROLE OF CUSTOMER SATISFACTION IN MEDIATING THE EFFECT OF BRAND IMAGE AND PERCEIVED QUALITY ON BRAND LOYALTY: A STUDY ON BATA BRAND CONSUMERS IN DENPASAR
}

\author{
Sudana Ni Made Ardanereswari Damayanti*, Setiawan Putu Yudi \\ Faculty of Economics and Business, University of Udayana, Bali, Indonesia \\ `E-mail: ardanereswari@gmail.com
}

\begin{abstract}
Footwear is one of the fashions for both men and women. One of the companies that produce well-known footwear brands is Bata. Based on the results of the pre-survey, it was found that there were disloyal and dissatisfied customers. Customers do not make Bata their first choice, and there is still dissatisfaction with their design. The purpose of this study is to explain the role of customer satisfaction in mediating the influence of brand image and perceived quality on brand loyalty to Bata brand customers in Denpasar. The number of samples in this study was 110 respondents, with purposive sampling method. Data collection is conducted by distributing questionnaires to customers of the Bata brand, and the analysis technique used is Structural Equation Modeling (SEM) on a variant basis with the SmartPLS tool. The result of this research is that brand image has a positive and significant effect on brand loyalty. Perceived quality has a positive and significant effect on brand loyalty. Brand image has a positive and significant and significant effect on customer satisfaction, as well as perceived quality has a positive and significant and significant effect on customer satisfaction. The mediating variable, customer satisfaction, is able to partially mediate brand image and perceived quality on brand loyalty. The practical implication of this research is that the Bata brand can evaluate the variables of brand image, perceived quality and customer satisfaction to increase brand loyalty. Based on statistical results, among the three variables that affect brand loyalty, customer satisfaction has the greatest influence. So, Bata management can make strategies to increase brand loyalty by increasing customer satisfaction.
\end{abstract}

\section{KEY WORDS}

Brand image, perceived quality, customer satisfaction, brand loyalty.

Footwear Company is one of the companies that are competing fiercely. Footwear is required to have good quality, both in terms of durability, comfort and being able to make someone who uses footwear with that brand satisfied. Footwear itself is a fashion support for an individual. There are many footwear brands spread across national and international markets originating from local and international companies. One of the footwear brands in Indonesia is Bata. Bata itself is a footwear brand founded by Thomas Bat'a where the factory was first built in Zin, Czechoslovakia, which later spread to various countries including Indonesia, under the company name PT Shoes Bata Tbk. The decline in sales was supported by weak sales of domestic products in 2017 by $2.73 \%$ to Rp 961.10 billion compared to 2016 of Rp 988.09 billion (Cnbcindonesia, 2018). Net sales decreased by around 5.58\% from Rp 762.17 billion in 2018 to Rp 721.85 billion in 2019 (Indutsri.kontan, 2019). The decline in sales could be due to other brands such as Fladeo which experienced an increase in 2018. In 2019 and 2020 the Carvil brand began to appear which entered the top two top brand indexes, which caused the Bata brand to be competitive. In addition, in 2020, due to the COVID-19 pandemic, Bata again experienced a decline in demand for both domestic and export with a deeper decline of up to $54.07 \%$ to $\mathrm{Rp} 228.97$ billion in 2020 (Industry.kontan, 2020).

High and low sales of a product or brand, one of which depends on whether the product is in demand or not by customers (Arifin, 2015). One of the possible causes for the decline in sales of the Bata brand is that consumers switch to new, more famous and modern 
brands (Hasyyati and Imroatul, 2019). Brand loyalty according to Rather (2018) is when customers make repeat purchases or repeat visits (behavioral loyalty) to a product or service and they will recommend the company of the product to others and give a positive attitude towards the company. According to Kurniawan (2017), brand loyalty shows the existence of a bond between customers and certain brands and this is often marked by repeat purchases of customers. A strong relationship between a customer and a brand not only maintains future business relationships, but also enhances other beneficial values such as the initiative to recommend and contribute to the company's positive reputation. The uniqueness of a product will motivate customers to keep choosing the product, and this uniqueness can be attached to a brand which in turn increases customer loyalty to the brand (Shanahan et al., 2019). Variables that can affect loyalty are brand image and perceived quality (Kim et al., 2018). An initial pre-survey conducted to 30 respondents on October 21, 2020, to Bata brand customers in Denpasar using open questionnaires and interviews, it was obtained data that Bata still has shortcomings in its products.

Table 1 - Bata Sales from 2017-2020 (IDR)

\begin{tabular}{ccc}
\hline Year & Sales & Sales Drop \\
\hline 2017 & 961,10 billion & 26,99 billion \\
\hline 2018 & 762,17 billion & 198,93 billion \\
\hline 2019 & 721,85 billion & 40,32 billion \\
\hline 2020 & 228,97 billion & 492,88 billion \\
\hline
\end{tabular}

Source: Industri.kontan 2020.

Table 2 - Pre-survey Results on 30 Brand Bata's Respondents

\begin{tabular}{lcc}
\hline \multicolumn{1}{c}{ Statement } & Yes & No \\
\hline Do you think the Bata brand is comfortable to use? & 26 & 4 \\
\hline Do you think the Bata brand has an attractive design? & 18 & 12 \\
\hline When you need footwear, is the Bata brand the first thing that comes to your mind? & 6 & 24 \\
\hline Do you think the price and quality of the Bata brand is right for you? & 17 \\
\hline Are you satisfied with the Bata brand? & 13 \\
\hline Are you loyal to the Bata brand? & 14 \\
\hline
\end{tabular}

Source: Primary Data, processed (2020).

The results of the pre-survey are presented in table 2, in terms of perceived quality, Bata has a less modern impression, some products are comfortable and some are not. Then in terms of brand image, according to consumers, some Bata products do not match the price. Where the price is expensive with product designs that are less trendy for young people and seem old-fashioned. Likewise, according to parents who have a high fashion spirit. Bata does not give an attractive impression on the product, and makes people who use it feel normal, and is not the first choice when they want to buy footwear. It is very rare for the Bata brand to cross consumers' minds when they want to buy footwear.

Based on the results of the pre-survey, it was found that 16 people were loyal to the Bata brand, and 14 people were disloyal. According to these disloyal customers, they are not satisfied with the perceived quality and brand image of the Bata brand. Mostert et al. (2016) say that as a marketer it is necessary to develop an understanding of consumer needs, so that consumer needs are met, so as to create consumer satisfaction which becomes brand loyalty. As already mentioned Kim et al. (2018), one that affects brand loyalty is brand image. When a company has a good and strong brand image, it will certainly increase the company's reputation. In the case of Bata, Bata's brand image in the eyes of consumers has declined. Brand Image according to Budiyanto et al. (2017) is a concept created by the customer due to his subjective reasons and personal emotions. Environmental and personal factors as the beginning of the formation of a brand image, because environmental and personal factors affect one's perception.

Based on the case of Bata, the brand image index decreased in the eyes of consumers. As presented in table 1 where the index has decreased from 2017 to 2020 by 
6.8\%. In addition, in the pre-survey, it was found that the Bata brand rarely crosses consumers' minds when it comes to footwear. Research by Prasetya et al. (2018), states that a company that is able to form a good brand image will be able to carry out promotions easily and effectively to consumers who have great opportunities in increasing customer loyalty but if it has a bad brand image it will be valuable otherwise. Gupta and Anushree (2018) state that consumers will be attracted to brands that not only have a socially acceptable brand image within the group, but also recognized quality standards among associative reference groups.

According to Aberdeen et al. (2016) when a brand is considered prestigious by consumers, the higher the brand equity, so that it will attract consumers to buy the brand. Research results Kim et al. (2018) found that brand image has a positive and significant effect on brand loyalty. These results are supported by research by Nofriyanti (2017), Bilgin (2018) and Brangsinga et al. (2019) where brand image has a positive and significant effect on brand loyalty. Research results Ali et al. (2020) also get the same results where brand image has a positive and significant influence on brand loyalty.

Different results were obtained by Alkhawaldeh et al. (2016), where it was found that brand image has an insignificant positive effect on brand loyalty. This is not significant because consumers when buying products are not concerned with brand image, be it brand popularity, company reputation and product design. Research by Marliawati and Dwi (2020) found that brand image has a positive but not significant effect on brand loyalty. So that the influence of Bata's brand image on brand loyalty needs to be considered.

In addition to brand image, the determinant of brand loyalty is perceived quality. Perceived quality according to Khoso et al. (2016) are opinions from consumers about the ability of a product, service or brand to meet consumer expectations. In the study of Lubis et al. (2018), states that the higher one's perception of quality, the higher the likelihood of one's intention to buy. Supported by Rahmawan and Suwitho (2020), when consumers have a good level of understanding of a brand, it will make consumers have a good perception of the quality of the brand. A competitive market, the battle lies not only in tariffs and products, but also in consumer perceptions. When the company is able to make products according to consumer perceptions, of course consumer satisfaction and loyalty will increase, and lead to increased consumer purchases.

The research results of Shanahan et al. (2019) found that perceived quality has a positive and significant effect on brand loyalty. These results are supported by the research of Kim et al. (2018), Brangsinga et al. (2019), Amelia (2018) and Fajariah et al. (2016) where the result is that perceived quality has a positive and significant effect on brand loyalty. In contrast to the research results of Rahmatullah et al. (2018), where perceived quality has no significant effect on brand loyalty. According to the results of the study, good perceived quality will not increase customer brand loyalty.

In the pre-survey conducted, it was found that 16 respondents were satisfied with the Bata brand because the brand image and its quality is good, thus making them satisfied and loyal, while 14 respondents were dissatisfied and disloyal to the Bata shoe brand. According to Rather (2018), customer satisfaction is the feeling of consumers when the product or service meets their expectations. The emergence of satisfaction can be due to a good company image or image. According to Kataria et al. (2019), high customer satisfaction is able to make customers loyal to a product. Because, satisfaction has a positive impact on the minds of customers who make customers loyal.

The research results of Semuel et al. (2019) found that brand image has a positive and significant effect on customer satisfaction. These results are in accordance with the research of Hoseini et al. (2017), Nawi et al. (2019) and Ali et al. (2020) where brand image has a positive and significant effect on customer satisfaction. Another study conducted by Izzudin and Weni (2018) found that brand image has a significant effect on customer satisfaction. In contrast to the results of Wahyuni and Imam (2019) that brand image has no influence on customer satisfaction. When a company's brand image is good, it doesn't necessarily make customers satisfied. Consumer satisfaction can also arise when the product or service matches the perceived quality (Suryani, 2018). According to Moorthy et al. (2018), where the 
perception of good quality will strongly increase consumer satisfaction. Therefore, perceived quality is an important determinant of customer satisfaction. The research results of Moorthy et al. (2018) states that perceived quality has a significant influence on consumer satisfaction. The results of this study are supported by the results of research by Mbambonduna (2018), Kataria and Vinod (2019), Faizal and Siti (2019) and Izzudin and Weni (2018), where perceived quality has a positive and significant effect on customer satisfaction. In contrast to the results of Januarko et al. (2018) where the perception of quality has no effect on customer satisfaction.

Getting loyal customers, consumer needs need to be satisfied consistently from time to time. The higher the customer satisfaction, the more loyal consumers are to the product brand. The results of Mostert et al. (2016), where customer satisfaction has a positive and significant effect on brand loyalty. Supported by the results of Widjaja (2016), Kim et al. (2016) and Rahther (2018) where customer satisfaction has a positive and significant influence on brand loyalty. Another study which found that customer satisfaction had a positive and significant effect on brand loyalty was the research of Kataria and Vinod (2019). The results of the study of Tee et al. (2018) give different results, where customer satisfaction has no effect on loyalty. Based on the phenomena and previous research, the formulation of the hypothesis and the conceptual framework formed are as follows:

$\mathrm{H} 1$ : brand image has a positive and significant effect on brand loyalty;

$\mathrm{H} 2$ : brand image has a positive and significant effect on customer satisfaction;

H3: perceived quality has a positive and significant effect on brand loyalty;

$\mathrm{H} 4$ : perceived quality has a positive and significant effect on customer satisfaction;

H5: customer satisfaction has a positive and significant effect on brand loyalty;

H6: customer satisfaction can mediate brand image on brand loyalty;

H7: customer satisfaction can mediate perceived quality on brand loyalty.

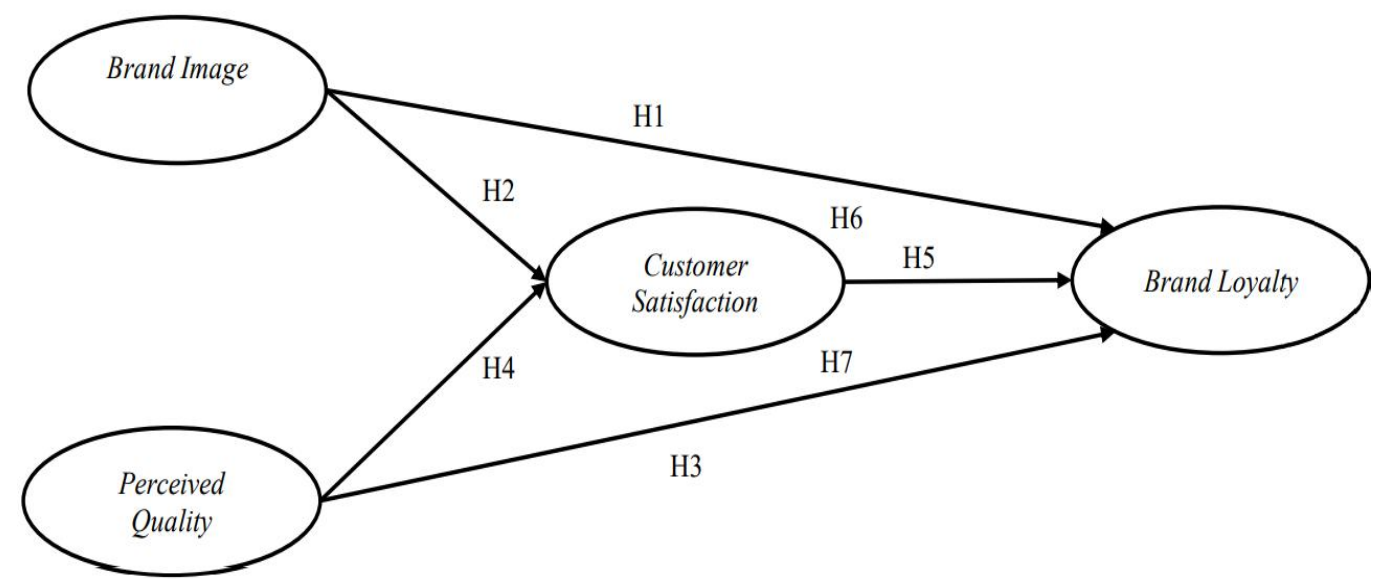

Figure 1 - Conceptual Framework (Source: Izzudin and Weni, 2018; Kim et al., 2018; Mostert et al, 2016)

\section{METHODS OF RESEARCH}

The initial design of this study was to increase the competitiveness of the Bata brand. The scope of the research is on customers who have bought Bata brand products in Denpasar. The objects studied in this study are perceived quality, brand image, customer satisfaction and brand loyalty to the Bata brand. The population in this study is customers of the Bata brand in Denpasar whose number cannot be ascertained (infinite). The best sample size for measuring multivariate is $5-10$ times the number of indicators. The number of samples used is the number of indicators multiplied by five. The indicators used are 22 indicators, so the sample to be used is $22 \times 5=110$ respondents. The data analysis method used is descriptive and inferential analysis and uses the VAF test to test mediation. 


\section{RESULTS AND DISCUSSION}

Characteristics of respondents seen in this study are based on gender, age, and occupation. The number of respondents in this study was 110 people who were distributed using google form from April 14, 2021 to April 27, 2021. Based on the data obtained through questionnaires, the results obtained are as in Table 5.1, where the number of respondents who have female is $63.6 \%$ while male respondents are $36.4 \%$. Respondents with jobs as private employees are more than $36 \%$. Respondents aged $20-25$ years at most with a percentage of $45 \%$. Characteristics of respondents are used as information that for respondents who buy Bata products more women than men with a percentage of women $63.6 \%$. As for the age of respondents who bought Bata products, the highest was between the ages of 21-25 years at $45 \%$ and the occupations were private employees $36 \%$.

Table 3 - R-square test results

\begin{tabular}{cc}
\hline $\mathrm{n} / \mathrm{n}$ & $R$ Square \\
\hline Customer Satisfaction & 0.827 \\
\hline Brand Loyalty & 0.863 \\
\hline
\end{tabular}

Source: Primary Data, processed (2021).

Based on Table 3, it can be seen that the R-square of the brand loyalty variable is 0.863 which indicates that $86.3 \%$ of the variability of the brand loyalty variable is explained by the brand image, perceived quality and brand loyalty variables. While $13.7 \%$ is explained by other variables outside the model. Then for customer satisfaction, the R-square value is 0.827 , which means $82.7 \%$ of the customer satisfaction variable is explained by the brand image and perceived quality variables, while $17.3 \%$ is explained by variables from outside the model.

Table 4 - Result of Direct effect test

\begin{tabular}{lcccc}
\hline \multicolumn{1}{c}{$\mathrm{n} / \mathrm{n}$} & Path coef. & T Statistics $(|\mathrm{O} / \mathrm{STDEV}|)$ & $\mathrm{P}$ Values & Info. \\
\hline Brand Image $->$ Brand Loyalty & 0,193 & 2,021 & 0,022 & Sig. \\
\hline Brand Image $->$ Customer Satisfaction & 0,218 & 2,299 & 0,011 & Sig. \\
\hline Perceived Quality $->$ Brand Loyalty & 0,350 & 2,792 & 0,003 & Sig. \\
\hline Perceived Quality $\rightarrow$ Customer Satisfaction & 0,712 & 7,485 & 0,000 & Sig. \\
\hline Customer Satisfaction $\rightarrow$ Brand Loyalty & 0,422 & 3,435 & 0,000 & Sig. \\
\hline
\end{tabular}

Source: Primary Data, processed (2021).

The path coefficient results in table 4 on the T statistic value will be compared with the $\mathrm{t}$ count value, where if the t statistic is 1.96 (t-table), then $\mathrm{H} 0$ is rejected. In addition, it is also seen that the $p$-value must be $<0.05$.

Table 5 - Mediation Variable Test Results

\begin{tabular}{|c|c|c|c|c|c|}
\hline \multirow{2}{*}{ Variables Relationship } & \multicolumn{4}{|c|}{ Effect } & \multirow{2}{*}{ Info. } \\
\hline & $(\mathrm{A})$ & $(\mathrm{B})$ & $(\mathrm{C})$ & (D) & \\
\hline $\begin{array}{l}\text { Brand Image (X1) -> Customer satisfaction (Y1) -> } \\
\text { Brand Loyalty (Y2) }\end{array}$ & $\begin{array}{l}0,092 \\
\text { (Sig.) }\end{array}$ & $\begin{array}{l}0,193 \\
\text { (Sig.) }\end{array}$ & $\begin{array}{l}0,218 \\
\text { (Sig.) }\end{array}$ & $\begin{array}{l}0,422 \\
\text { (Sig.) }\end{array}$ & $\begin{array}{c}\text { Partial } \\
\text { Mediation }\end{array}$ \\
\hline $\begin{array}{l}\text { Perceived Quality (X2)-> Customer satisfaction (Y1) -> } \\
\text { Brand Loyalty (Y2) }\end{array}$ & $\begin{array}{l}0,301 \\
\text { (Sig.) }\end{array}$ & $\begin{array}{l}0,350 \\
\text { (Sig.) }\end{array}$ & $\begin{array}{l}0,712 \\
\text { (Sig.) }\end{array}$ & $\begin{array}{l}0,422 \\
\text { (Sig.) }\end{array}$ & $\begin{array}{l}\text { Partial } \\
\text { Mediation }\end{array}$ \\
\hline
\end{tabular}

Source: Primary Data, processed (2021).

The description of each effect $(A),(B),(C)$, and $(D)$ is as follows:

$(A)$ : indirect effect of exogenous variables (X1 or $X 2)$ on endogenous variables $(Y 2)$;

(B): direct effect of exogenous variables (X1 or $\mathrm{X} 2$ ) on endogenous variables (Y2);

(C): direct effect of exogenous variables (X1 or $\mathrm{X} 2)$ on endogenous variables (Y1);

(D): direct effect of endogenous variable (Y1) on endogenous variable (Y2).

The criteria for assessing the mediating effect can be based on the VAF value. If the VAF value is $>0.80$ then the mediation is said to be full mediation, when the VAF value is in the range $\geq 0.20$ to 0.80 it is said to be partial mediation, and if $<0.20$ it is said there is no mediation. 
Table 6 - Indirect Influence Test Results

\begin{tabular}{|c|c|c|c|c|}
\hline & Path Coef. & T Statistics (|O/STDEV|) & P Values & Info. \\
\hline Brand Image -> Customer satisfaction -> Brand Loyalty & 0,092 & 2,071 & 0,019 & Sig. \\
\hline Perceived Quality -> Customer satisfaction -> Brand Loyalty & 0,301 & 2,797 & 0,003 & Sig. \\
\hline
\end{tabular}

Source: Primary Data, processed (2021).

Table 7 - Total Influence Results

\begin{tabular}{lcc}
\hline \multicolumn{1}{c}{ Variable } & Path Coef. & T Statistics $(|\mathrm{O} / \mathrm{STDEV}|)$ \\
\hline Brand Image $->$ Brand Loyalty & 0,286 & 2,903 \\
\hline Brand Image $->$ Customer Satisfaction & 0,218 & 2,299 \\
\hline Customer Satisfaction $->$ Brand Loyalty & 0,422 & 3,435 \\
\hline Perceived Quality $->$ Brand Loyalty & 0,651 & 6,788 \\
\hline Perceived Quality $->$ Customer Satisfaction & 0,712 & 7,485 \\
\hline
\end{tabular}

Source: Primary Data, processed (2021).

Based on Tables 6 and 7, calculations were carried out to obtain the VAF value, namely the indirect effect divided by the total effect. The following are the results of calculations for the two hypotheses with mediation.

The VAF value for the role of customer satisfaction in mediating the influence of brand image on brand loyalty is 0.32 which is in the range of 0.20 to 0.80 .

$$
\text { VAF }=\frac{\text { indirect effect }}{\text { direct effect }}=\frac{0,092}{0,286}=0,32
$$

This means that the customer satisfaction variable is classified as a partial mediation variable. In conclusion, customer satisfaction can partially mediate the effect of brand image on brand loyalty. The VAF value for the role of customer satisfaction in mediating the effect of perceived quality on brand loyalty is 0.46 which is in the range of 0.20 to 0.80 .

$$
\mathrm{VAF}=\frac{\text { indirect effect }}{\text { direct effect }}=\frac{0,301}{0,651}=0,46
$$

This means that the customer satisfaction variable is classified as a partial mediation variable. In conclusion, customer satisfaction can mediate the effect of perceived quality on brand loyalty.

The Effect of Brand Image on Brand Loyalty. The brand image variable has a positive and significant effect on brand loyalty. This means that the brand image variable is able to increase consumer loyalty to the Bata brand in Denpasar. The better the Bata brand image, the higher the loyalty of customers to the Bata brand. Indicators that are in the dimensions of favourability, strengthness and uniqness can be used to improve Bata's brand image.

In building brand loyalty, a company must improve the image of the brand. Products that have high quality will increase satisfaction, so that consumer loyalty will be obtained for the brand (Ali et al., 2020). Customers will tend to pay attention to the brand image of a product that will be used, especially in footwear. When someone uses a brand that is well known, it will certainly create loyalty from the customer, especially if the brand has its own uniqueness that is able to attract customers. According to Aberdeen et al. (2016) when a brand is considered prestigious by consumers, the higher the brand equity, so that it will attract consumers to buy the brand.

Shanahan et al. (2019) said, the uniqueness of a product will motivate customers to continue to choose the product, and this uniqueness is able to attach to the brand which in turn increases brand loyalty to the brand. The results of this hypothesis are in line with the research of Kim et al (2018), Ali et al (2020), Nofriyanti (2017), Bilgin (2018) and Brangsinga et al. (2019) where brand image has a positive and significant effect on brand loyalty. Where, to get customer loyalty for a brand, it takes an increase in brand image.

The Effect of Brand Image on Customer Satisfaction. Brand image has a positive and significant influence on customer satisfaction. This means that the better the brand image of a product, the higher customer satisfaction. Customer satisfaction is based on the feeling of 
pleasure or disappointment obtained when comparing the expected results of the product. Research by Ali et al (2020) states that the product image of a company can increase consumer buying interest by offering high quality products, increasing satisfaction and level of trust and building loyalty to product brands in the company. Hosseini's research (2017) found that consumer satisfaction will increase when the brand image of the company is good. These results are in line with the research of Semuel et al. (2019) states that a good brand image can increase customer satisfaction. These results are in accordance with the research of Hoseini et al. (2017), Nawi et al. (2019) and Ali et al. (2020). Another study conducted by Izzudin and Weni (2018) found that brand image has a significant effect on customer satisfaction.

The Influence of Perceived Quality on Brand Loyalty. Perceived quality has a positive and significant effect on brand loyalty. This means that good perceived quality will increase brand loyalty from customers. Shanahan et al (2019) stated that perceived quality can be one of the marketing tools to increase customer brand loyalty. The uniqueness of a product will motivate customers to stay involved and attached to the brand which in turn increases the perception of quality and brand loyalty to the brand.

When consumers have a good level of understanding of a brand, it will make consumers have a good perception of the quality of the brand. The resulting product is able to match consumer perceptions, will increase customer loyalty to the brand and lead to increased consumer purchases. In the case of Bata, the company must increase the perception of the quality of the Bata brand in the minds of consumers to increase brand loyalty. The results of the research by Shanahan et al (2019) found that perceived quality has a positive and significant effect on brand loyalty. These results are supported by research by Kim et al (2018), Fajariah et al. (2016), Amelia (2018), Ali et al (2020) and Brangsinga et al (2019) where the result is that perceived quality has a positive and significant influence on brand loyalty.

Influence of Perceived Quality on Customer Satisfaction. Customer satisfaction has a positive and significant effect on brand loyalty. This means, good perceived quality will increase customer satisfaction for the Bata brand. According to Moorthy et al. (2018), where the perception of good quality will strongly increase consumer satisfaction. Therefore, perceived quality is an important determinant of customer satisfaction.

Izzudin and Weni (2018) mention that good perceived quality will have a big impact on customer satisfaction. The more improving the quality of a product, the more customer satisfaction will increase. Likewise with the results of Faizal and Siti's research (2019), where the better the perception of quality, the more customer satisfaction will increase. The results of this study are in line with the research of Izzudin and Weni (2018), Moorthy, et al. (2018), Mbambonduna (2018), and Kataria and Vinod (2019) where perceived quality has a significant influence on customer satisfaction.

The Influence of Customer Satisfaction on Brand Loyalty. Brand loyalty is based on customer satisfaction. High customer satisfaction, able to make customers loyal to a product. Because, satisfaction has a positive impact on the minds of customers who make customers loyal. Satisfaction according to Oliver (1980) is the level of one's feelings (customers) after comparing the perceived performance or results with those expected.

Brand loyalty will not exist without customer satisfaction. Therefore, marketers must develop an understanding of consumer needs, so that consumer needs are met, so that consumer satisfaction is created which becomes brand loyalty (Mostert et al., 2016). The results of this study, it was found that customer satisfaction has a positive and significant effect on brand loyalty. Increasing customer loyalty to the Bata brand can be done by increasing customer satisfaction first, such as satisfaction with the product because it is in accordance with customer expectations and satisfied with the price according to the condition of the product. These results are in accordance with the research of Mostert et al (2016) and Kataria and Vinod (2019) where customer satisfaction has an effect on brand loyalty. Supported by the results of Widjaja (2016), Kim et al. (2016), Rather (2018) where customer satisfaction has a positive and significant influence on brand loyalty. Rather (2018) research states that consumer satisfaction can increase brand loyalty. When consumers are satisfied, consumers will become loyal. 
The Role of Customer Satisfaction in Mediating the Effect of Brand Image on Brand Loyalty. Brand image is one of the determinants of customer satisfaction and loyalty. Based on the statistical results obtained, that customer satisfaction is able to mediate the effect of brand image on brand loyalty. The better the brand image and customer satisfaction, it will increase brand loyalty directly or indirectly to the Bata brand. Customer satisfaction becomes a partial mediation in increasing brand loyalty. It can be said that brand loyalty can be increased by brand image directly, in addition, brand loyalty will increase again if customer satisfaction is also able to increase brand loyalty. Brand Bata can improve the brand image of its products, so that later customer satisfaction will appear, which can increase loyalty. customers towards the Bata brand. This is in line with the research of Ali et al (2020), Nofriyanti (2017), Hoseini, et al. (2017), Mostert et al (2016) and Nawi et al (2019).

The Role of Customer Satisfaction in Mediating the Effect of Perceived Quality on Brand Loyalty. In addition to brand image, there is a perceived quality variable that determines brand satisfaction and loyalty. In this study, customer satisfaction is able to mediate the effect of perceived quality on brand loyalty. The results obtained, that customer satisfaction becomes a partial mediation, which means that brand loyalty can be increased by perceived quality directly, in addition, brand loyalty will increase again if customer satisfaction is also able to increase brand loyalty.

The better the perception of quality for the Bata brand, of course, it will increase customer satisfaction for the Bata brand which will indirectly increase brand loyalty to the Bata brand. So it can be said that consumer satisfaction is able to mediate in this study. Customers will have a sense of satisfaction when the perceived quality of a product is as expected, so that when consumers are satisfied, it will lead to brand loyalty. The results of this study are in line with the results of previous studies, which according to Shanahan et al (2019), Mbambonduna (2018), Moorthy et al (2018), Kataria and Vinod (2019) and Mostert et al (2016).

Implications. This study results that to increase brand loyalty, we must pay attention to brand image, perceived quality, and customer satisfaction. The mediating variable of this research is customer satisfaction, which means it has the main key in increasing brand loyalty. When a company produces products with a brand name, of course the company wants loyal customers and always buys its products. Apart from being satisfied with the brand image, customers are also satisfied with the quality of the brand, both in terms of services and products. So that it can increase customer loyalty. Keeping the brand image so that the brand remains good, the company can develop an attractive product display as possible to become strength for Bata and always be remembered by customers. Then in terms of perceived quality is to produce products with attractive colors. Attractive colors are also based on the type of color quality used. So that it will have an impact on customer satisfaction and create brand loyalty to the Bata brand.

Limitations. The limitations of the research in this study are that this study uses a crosssectional approach or at a certain point in time. So it cannot be used to observe the dynamics of conditions that change every period, therefore it is important to re-examine in the future. This research is only limited to the variables of brand image, perceived quality, customer satisfaction and brand loyalty. Where further researchers can use other variables in increasing brand loyalty.

\section{CONCLUSION}

Based on the discussion that has been explained, the conclusion of this study is that brand image has a positive and significant effect on brand loyalty. Brand image has a positive and significant effect on customer satisfaction. Perceived quality has a positive and significant effect on brand loyalty. Perceived quality has a positive and significant impact on customer satisfaction. Customer satisfaction has a positive and significant effect on brand loyalty. The role of customer satisfaction in mediating the influence of brand image on brand loyalty is partial mediation. The role of customer satisfaction in mediating the effect of perceived quality on brand loyalty is partial mediation.

The suggestion from this research is that the Bata brand consistently releases a model that varies every week and emphasizes the product more, by placing new products in the front area, so that it can become an icon and improve the Bata brand image as a uniqueness 
that customers can remember because of this uniqueness., and can conduct surveys on design developments and trends in the current market. So that it can produce products that suit current market tastes. Give a positive impression to customers by providing quality products and attractive prices. So that later a positive impression from customers who have bought the Bata brand will recommend Bata to others.

\section{REFERENCES}

1. Abberden, Naufal Iza, Muhammad Syamsun and Mukhamad Najib. 2016. The Effect of Brand Awareness and Image on Consumer Perceived Quality and Purchase Intention A Study Case of Carbonated Drink Brand at Bogor City. International Journal of Scientific and Research Publications. Vol 6, Issue 8, pp: 441-446.

2. Ali, Afzaal, Mehkar Sherwani, Adnan Ali, Zeeshan Ali and Mariam Sherwani. 2020. Investigating The Antecedents Of Halal Brand Product Purchase Intention: An Empirical Investigation. Journal of Islamic Marketing.

3. Alhaddad, Abdullah. 2015. Perceived Quality, Brand Image and Brand Trust as Determinants of Brand Loyalty. Journal of Reasearch in Business and Management. Vol. 3, Issue 4, pp: 01-08.

4. Alkhawaldeh, Abdelbaset M., Salniza Md. Salleh and Fairol Bin Halim. 2016. Brand Equity and Brand Loyalty: New Perspective. International Review of Management and Marketing. Vol. 6, Issue 4, pp: 722-730.

5. Amelia, Shelly. 2018. The Effect of Perceived Quality, Brand Awareness, and Brand Loyalty Toward Brand Equity of Beer Bintang in Surabaya. Jurnal IImiah Mahasiswa Universitas Surabaya. Vol. 7, No.1, Hal 899-918.

6. Arifin, Endro and Achman Fachrodji. 2015. Pengaruh Persepsi Kualitas Produk, Citra Merek and Promosi Terhadap Minat Beli Konsumen Ban Achilles Di Jakarta Selatan. Jurnal MIX, Vol. V, No. 1.

7. Asshidin, Nor Hazlin Nor., Nurazariah Abidin, and Hafizzah Bashira Borhan. 2016. Perceived Quality and Emotional Value That Influence Consumer's Purchase Intention Towards American And Local Products. Procedia Economic and Finance. 35, pp: 639-643.

8. Bilgin, Yusuf. 2018. The Effect of Social Media Marketing Activities on Brand Awareness, Brand Image and Brand Loyalty. Buseiness \& Management Studies: An International Journal. Vol. 6 Issue 1, pp: 128-148.

9. Budiyanto, Albert., Diska Destilestari. 2017. Pengaruh Citra Merek, Kualitas Produk and Harga Terhadap Minat Beli Konsumen pada Smartphone Merek Samsung. ESENSI. Vol. 20, No. 3, Hal: 79-101.

10. Brangsinga, Gusti Bagus Yopi and Tjok Gde Raka Sukawati. 2019. Pengaruh Perceived Quality and Brand Image Terhadap Brand Loyalty and Brand Equity. E-Jurnal Manajemen. Vol. 8 N0. 4, Hal: 2125-2151.

11. Faizal, Hanim and Siti Nurjanah. 2019. Pengaruh Persepsi Kualitas and Citra Merek Terhadap Loyalitas Pelanggan Dimediasi Kepercayaan and Kepuasan Pelanggan. Jurnal Riset Manajemen and Bisnis. Vol.4 No.2, hal: 307-316.

12. Fajariah, Nuraidya, Armanu Thoyib and Fatchur Rahman. 2016. Pengaruh Brand Awareness, Perceived Quality, Terhadap Brand Loyalty pada Generasi Y di Indonesia. Jurnal Aplikasi Management. Vol 14, No 3, hal: 471-480.

13. Gupta, Ashish and Anushree Tandon. 2018. Branding for Bottom of the Pyramid: A Case of Branded Footwear Consumer in Indian Rural Setting. Springer International Publishing. https://doi.org/10.1007/978-3-319-75013-2_20.

14. Gunadi, Fandy Arya, Michael Adiwijaya and Hartono Subagio. 2017. Pengaruh Perceived Quality terhadap Brand Loyalty dengan Brand Image and Brand Trust sebagai Variabel Intervening pada Merek Laptop Buatan Indonesia. Petra Business \& Management Review. Vol. 3, No. 2, pp: 84-105.

15. Ghozali, Imam. 2011. Aplikasi Analisis Multivariate Dengan Program IBM SPSS19. Semarang: Badan Penerbit Universitas Diponegoro. 
16. Hair, J. H., Black, W. C., Babin, B. J., \& Anderson, R. E. 2010. Multivariate Data Analysis Seventh Edition. Harlow: Pearson Pretince Hall.

17. Hasyyati, Rr Diva Putri and Imroatul Khasanah. 2019. Analisis Pengaruh Kualitas Produk, Persepsi Harga, and Citra Merek Terhadap Keputusan Pembelian Produk Toko Sepatu Bata Dengan Minat Beli Sebagai Mediasi (Studi Pada Konsumen Toko Sepatu Bata Semarang). Diponegoro Journal Of Management. Vol. 8, No. 4, Hal. 58-69.

18. Hosseini, Sayed Hamid Khodadad and Leila Behboudi. 2017. Brand Trust And Image: Effects On Customer Satisfaction. International Journal of Helath Care Quality Assurance, Vol. 30 Issue 7 pp. 580-590.

19. Izzudin, Muhammad and Weni Novandari. 2018. The Perfect of Perceived Quality, Brand Image on Customer Satisfaction and Brand Awareness toward Repurchase Intention. Jurnal of Research in Management. Vol 1 No 3, pp. 32-43.

20. Januarko, Moehammad Unggul, Bugisatrio and Ariwibowo. 2018. Effect Product Quality, Price Perception, Customer Satisfaction Batk Betawi Loyalty in Jakarta. IOSR Journal of Business and Management. Vol. 20, Issue 8, pp. 1-7.

21. Kataria, Sonia and Vinod Saini. 2019. The Mediating Impact Of Customer Satisfaction In Relation Of Brand Equity And Brand Loyalty An Empirical Synthesis And ReExamination. South Asian Journal of Business Studies, Vol. 9 No. 1, pp. 62-87.

22. Kim, Seongseop (Sam), Ja Young (Jacey) Choe and James F. Trick. 2018. The Effect Of Celebrity On Brand Awareness, Perceived Quality, Brand Image, Brand Loyalty, And Destination Attachment To A Literary Festival. Journal of Destination Marketing \& Management.

23. Kurniawan, Hironimus Hari. 2017. Pengaruh Perceived Quality Terhadap Brand Loyalty Melalui Mediasi Brand Image and Brand Trust (Studi Pada Brand Restoran Mcdonald's Di Kota Malang). Jurnal Bisnis and Manajemen, Vol. 4, No. 2.

24. Kotler, and Keller. 2012. Manajemen Pemasaran. Edisi 12. Jakarta: Erlangga.

25. Kotler, Philip and Kevin Lane Keller, 2016. Marketing Management, 15th Edition, Pearson Education, Inc.

26. Kim, Soon-Ho, Min-Seong Kim and Dong Hun Lee. 2017. The Effects Of Personality Traits And Congruity On Customer Satisfaction And Brand Loyalty: Evidence From Coffee Shop Customers. In Advances in Hospitality and Leisure. Vol 12, 3-33.

27. Marliawati, Annisa and Dwi Cahyaningdyah. 2020. Impact the Brand of Experience and Brand Image on Brand Loyalty: Mediators Brand of Trust. Management Analysis Journal. Vol. 9, Issue. 2.

28. Mbambonduna, Thobeka. 2018. Extrinsic and Intrinsic Footwear Cues' Influence on Perceived Quality and Consumer Satisfaction amongst Generation $Y$ in South Africa. Journal Of Business Sciences. Vol. 2, Issue 2.

29. Moorthy, Krishna, Loh Chun Ting, Seow Ai Na, Chew Tze Ching, Lee Yuin Loong, Lim Sze Xian and Teoh Wei Ling. 2018. Corporate Image No Longer Leads To Customer Satisfaction And Loyalty: A Malaysian Perspective. International Journal Law.

30. Mostert, P. G., D. J. Petzer and A. Weidman. 2016. The Interrelationships Between Customer Satisfaction, Brand Loyalty and Relationship Intentions of Generation $Y$ Consumers Towards Smart Phone Brands. South African Journal of Business Management 47 (3): 25-34.

31. Nawi, Noorshella Binti Che, Abdullah Al Mamun, Noorul Azwin Md Nasir, Azwan Abdullah and Wan Nurulasiah Wan Mustapha. 2019. Brand Image and Consumer Satisfaction Towards Islamic Travel Packages A Study On Tourism Entrepreneurship In Malaysia. Asia Pacific Journal of Innovation and Entreprenuership. Vol. 3 No.2 pp 188-202.

32. Natalia, Inpresta., Nurhayati and Eka Apria. 2020. Kualitas Layanan and Fasilitas Fisik Terhadap Kepuasan Peserta Didik (Studi Pada LP3I College Purwakarta). Jurnal Akuntansi Bisnis. Vol. 6, No. 1 pp 26-36.

33. Nurcahyo, Sofyan and Henny Welsa. 2017. Pengaruh Country Of Origin, Perceived Quality and Consumer Perception Terhadap Purchasing Intention Melalui Brand Image Sepeda Motor Honda Jenis Matic Di Kecamatan Bantul. Jurnal Manajemen Dewantara. Vol.1 No.2, pp: 12-24. 
34. Nofriyanti, Ayesha Rizky. 2017. Pengaruh Brand Trust, Brand Image, Perceived Quality, Brand Loyalty Terhadap Brand Equity Pengguna Telkomsel. Ekonomi Bisnis. Vol. 22, No. 2.

35. Oliver, Richard L. 1980. A Cognitive Model of The Antecedents and Consequences of Satisfaction Decisions. Journal of Marketing Research. Vol. XVII, pp. 460-469.

36. Oliver, Richard L. 1999. Whence Consumer Loyalty?. Journal of Marketing. Vol.63, pp. 33-44.

37. Prasetya, Ermawan Galih. Edy Yulianto and Sunarti. 2018. Pengaruh Brand Image Terhadap Keputusan Pembelian (Survei pada Mahasiswa Fakultas IImu Administrasi Bisnis Program Studi Administrasi Bisnis Angkatan 2014 konsumen Air Mineral Aqua). Jurnal Administrasi Bisnis, Vol. 62, No. 2.

38. Rahmawan, Ginanjar and Suwitho. 2020. The Influence of Brand mage, Brand Awareness, Perceived Quality on School Shoes Purchase Intention. International Conference on Business \& Social Science (ICOBUSS). pp: 514-523.

39. Rahmatulloh, Yasri and Abror. 2018. The Influence of Brand Image and Perceived Quality on Brand Loyalty with Brand Trust as Mediator in PT Bank Syariah Mandiri. Advances in Economics, Busness and Management Research Vol 64, hal: 569-578.

40. Rahmatina, Missfala, Saryadi and Sari Listyorini. 2016. Pengaruh Brand Image and Perceived Quality Terhadap Loyalitas Pelanggan Melalui Kepuasan Konsumen sebagai Variabel Intervening (Studi Kasus pada Maskapai Penerbangan Garuda Indonesia). Jurnal Administrasi Bisnis Undip, Vol. 5, No. 1. https://media.neliti.com/media/publications/105945-ID-pengaruh-brand-image-danperceived-quali.pdf.

41. Rather, Ahmah Raouf. 2018. Exploring Customers' Attitudes towards the Hospitality Brands in India: A Social Identity Perspective. The Branding of Tourist Destinations: Theoretical and Empirical Insights. Emerald Publishing Limited, pp. 207-231.

42. Schiffman, Leon G. and Joseph L. Wisenblit. 2015. Consumer Behaviour. Global Edition. $11^{\text {th }}$ Editon. Pearson.

43. Semuel, Hatane and Julian Wibisono. 2019. Brand Image, Customer Satisfaction and Customer Loyalty Jaringan Supermarket Superindo Di Surabaya. Jurnal Manajemen Pemasaran, Vol. 13, No. 1.

44. Setyadi, Fikri Kurnia, Suharyono and Aniesa Samira Bafadhal. 2018. Analisis Tingkat Loyalitas Merek (Survei Pada Pengguna Sepatu Casual Merek Adidas Di Kota Malang). Jurnal Administrasi Bisnis, Vol. 55 No. 2.

45. Setiadi, Nugroho J. 2013. Perilaku Konsumen. Edisi Revisi. Jakarta: Kencana Prenada Media Group.

46. Shanahan, Tyler, Trang P. Tran and Erick C. Taylor. 2019. Getting To Know You: Social Media Personalization As A Means Of Enhancing Brand Loyalty And Perceived Quality. Journal of Retailing Customer Service. 47, 57-65.

47. Suprapti, Sri Ni Wayan. 2010. Perilaku Konsumen (Pemahaman Dasar and Aplikasinya dalam Strategi Pemasaran). Udayana University Express.

48. Suryani, Cynthiawati Suci., Rini Andari and Taufik Abdullah. 2018. Pengaruh Perceived Quality terhadap Kepuasan Pengunjung di Museum Mandala Wangsit Siliwangi (Survei terhadap Wisatawan Museum Mandala Wangsit Siliwangi). Tourism and Hospitality Essentials Journal, Vol. 8 No. 2.

49. Sugiyono. 2018. Metode Penelitian Kuantitatif, Kualitatif, and R\&D. Bandung: Alfabeta.

50. Tee, Daniel Kasser, Alex Preko and Evans Tee. 2018. Understanding the Relationships between Service Quality, Customer Satisfaction and Loyalty: An Investigation Of Ghana's Retail Banking Sactor. British Journal of Marketing Studies.Vol. 6, No. 2, pp. 1-19.

51. Tjiptono, Fandi. 2011. Manajemen \& Strategi Merek. Yogyakarta: Andi.

52. Tjiptono, Fandi. 2015. Strategi Pemasaran. Edisi 4. Yogyakarta:. Andi.

53. Tiar, Putri Saptaning, Bambang Mursito and Burhanudin. 2019. Analisis Pembelian Sepatu Skechers Ditinjau dari Perceived Quality, Inovasi Produk and Kelompok Referensi di Solo Square Solo. Edunomika, Vol. 3 No. 2. 
54. Wahyuni, Sri and Imam Ghozali. 2019. The Impact of Brand Image and Service Quality on Consumer Loyalty in the Banking Sector. International Journal of Economics and Business Administration. Vol. VII, Issue 4.

55. Widjaja, Yani Restiani and Irpan Nugraha. 2016. Loyalitas Merek Sebagai Dampak Dari Kepuasan Konsumen. Jurnal Ekonomi and Bisnis Islam, Vol. 1 No. 1.

56. https://market.bisnis.com/read/20190430/192/917009/penjualan-sepatu-Bata-Bata-turun493. Diakses 10 Oktober 2020.

57. https://correcto.id/beranda/read/29692/ditengah-pandemi-corona-pabrik-masih-tutupsepatu-Bata-kehilangan-rp-4-7-miliar. Diakses 10 Oktober 2020.

58. https://industri.kontan.co.id/news/penjualan-turun-hingga-5391-sepatu-Bata-Batabukukan-rugi-rp-7449-miliar Diakses 10 Oktober 2020.

59. https://www.topbrand-award.com/ Diakses 10 Oktober 2020.

60. https://www.cnbcindonesia.com/market/20180403104118-17-9457/pendapatan-turun253-laba-bata-malah-naik-jadi-rp-53-m Diakses 10 Oktober 2020. 